\title{
The Curtin-Chifley Origins of the Australian Bank Deposit Guarantee
}

\author{
Chris Berg ${ }^{1}$
}

\section{Abstract}

In 2008, the Australian government introduced a guarantee of bank deposits. However, in 1945 the Curtin-Chifley government had already introduced what it believed was an explicit bank deposit guarantee. Using archival material, this paper shows how it was understood to be a guarantee by the cabinet, Labor parliamentarians, and the Commonwealth Bank. The guarantee was an important yet almost entirely forgotten part of the Curtin-Chifley government's social reform program. This paper uncovers the origins of the perception of a deposit guarantee in this forgotten 1945 debate, the attempts by policymakers and the Commonwealth Bank to roll back those perceptions in subsequent decades, and the Rudd government's reversion to an explicit guarantee scheme in 2008.

In 2008, the Australian government announced it would freely guarantee all retail and wholesale deposits in Australian banks, subsidiaries of foreignowned banks, credit unions and building societies. Until the global financial crisis, the Australian government, the Reserve Bank of Australia (RBA), and academics and commentators had repeatedly denied that any deposit guarantee existed (Edwards and Valentine 1998; Mitchell 2006; Quiggin 2002). At best what guarantee existed was an implicit guarantee; an assumption that the government would, in the case of a bank failure, step in to guarantee deposit liabilities ex post (Gray 2004). Regardless of that repeated denial, there had

1 Senior Fellow at Institute of Public Affairs, chrisberg@gmail.com. The author is a PhD candidate at RMIT University, and thanks Sinclair Davidson, Jason Potts and an anonymous referee for their valuable contributions. 
been a long-standing belief held by the public that their bank deposits were guaranteed by the Australian government. A 2006 survey by the RBA suggested that 60 per cent of Australians believed the Commonwealth government either directly guaranteed deposits or, if a bank failed, would ensure they received their money in whole or in part (Reserve Bank of Australia 2006). This paper addresses the origin of that public perception, and raises questions about the status of depositor protection between 1945 and 2008.

In 1945, the Curtin government introduced legislation to regulate the banking sector and formalise the central banking functions of the Commonwealth Bank. Section 13 of An Act to regulate Banking, to make provision for the Protection of the Currency and of the Public Credit of the Commonwealth and for other purposes 1945 (hereafter 1945 Banking Act) introduced a mechanism for the Commonwealth Bank to take over banks that could not meet their liabilities. This provision was taken by the Curtin government to be an explicit guarantee of depositors' funds. The government informed parliament, the public and, crucially, the Commonwealth Bank itself that this provision was intended to be a deposit guarantee. Furthermore, the language of the provisions remained relatively unchanged throughout many rounds of regulatory reform over the next seven decades.

This is not the first time it has been suggested that the 1945 Banking Act was understood to offer Australian depositors a full guarantee of their deposits. In a brief appendix to a paper outlining the history of prudential regulation in Australia, Hogan and Sharpe (1990) note that the Chifley government seemed to believe it had instituted a deposit guarantee scheme. Their evidence for this claim is suggestive, rather than definitive. Thomson and Abbott (2000) refer to documents in archives of the RBA that outline negotiations concerning the shape of the deposit guarantee but do not consider the political and regulatory significance of those documents.

Otherwise, histories of financial regulation in Australia assume that the 1945 Banking Act was not much interested in prudential and depositor protection issues. The received wisdom is summed up by an Australian Prudential Regulatory Authority Paper which states that the RBA did not guarantee the repayment of deposits. Instead the [Banking] Act conferred a number of powers on the RBA to ensure depositor protection' (Goldsworthy, Lewis and Shuetrim 2000: 3). The prudential aspects of the Banking Act have been subject to little scrutiny by economic historians. For example, in his history of the Commonwealth Bank, Giblin (1951) does not look at the relevant provisions of the Banking Act. Schedvin (1992: 68) notes the mechanism for Commonwealth Bank takeovers, but does not discuss it in detail, merely commenting that the power was 'inspired by the ghost of the 1890s banking crisis'. 
This paper brings to bear Lyons and Chifley government records and Commonwealth Bank archives on the origins of the deposit guarantee and how it was understood by the parliament, the Chifley government and the central bank. The paper begins by detailing the situation which prevailed before the 1945 Banking Act, and how governments reacted to banking failures in the depressions of the 1890s and 1930s. It then outlines the mechanism the 1936 Royal Commission into Monetary and Banking Systems devised by which insolvent and illiquid banks were to be taken over by the Commonwealth Bank. The paper then considers how the Labor government reconceived this mechanism from one which was to protect the stability of the banking system to one which it believed would provide a guarantee to depositors. RBA Archives show how the Commonwealth Bank negotiated with the government for more supervisory powers in order to protect itself against assuming financial responsibility for failed private banks. The paper then covers the parliamentary debate in order to understand how the legislature understood the guarantee, before examining how the perception of a guarantee faded. The relevant provisions of the Banking Act have never been tested. Discussions surrounding the Bank of Adelaide's demise in 1979 show how the RBA saw these provisions three decades after they were introduced. The paper concludes with some comments about how we should think about the trajectory of Australia's deposit guarantee in the light of these findings.

\section{Depositor protection before the 1945 Banking Act}

In 1893, 13 of Australia's 27 trading banks suspended payments, precipitating and contributing to a major financial crisis. Shudders in the economy had begun two years earlier, with the collapse of a number of building societies and land banks. This became a financial crisis with the suspension of the Federal Bank of Australia in January 1893, which was followed by a wave of bank suspensions in a panic at the end of April and early May.

Australia in the nineteenth century is usually described as one of the 'free banking' episodes in world history (Dowd 1992; Schuler 1992). There was little that could be described as 'prudential' regulation. Owners were subject to double liability and notes could only be issued on paid-up capital. What regulatory controls existed were poorly implemented and often ignored (Butlin 1953; Hickson and Turner 2004; Pope 1987; Turner 1904). Otherwise banks were regulated under general colonial companies law drawn from British companies acts or their own charters or private incorporating acts (Merrett 2013; Waugh 1992). Under colonial joint-stock company legislation, a minority of creditors had the right to force liquidation of a firm. With the financial system 
facing a drain on deposits in 1891 and 1892, both New South Wales and Victoria passed legislation to prevent such minority liquidation. These changes allowed a majority of creditors holding three-quarters of the firm's liabilities to come to a compromise with the firm that would be binding on the minority of creditors not party to that arrangement.

The amended company law set the stage for the reconstructions. The Associated Banks of Victoria disavowed any mutual assistance in March 1893, which has been seen as the proximate cause of the next few months' events (Butlin 1961; Coghlan 1918; Merrett 1993; Sykes 1988). The changes to liquidation policy encouraged banks to reconstruct: recapitalise with the funds of their depositors, in a new bank under the same name, and defer repayment of deposits. Shareholder and depositor meetings were stacked to achieve the new majority requirement for reconstruction plans (Sykes 1988: 183). Pope (1987: 29) argues this was a policy-induced crisis: 'One interpretation of the "crash" of April-May 1893 is of a rush by banks to seize the vantage ground offered by reconstruction.' Alternatively, in the view of Merrett $(1993,2013)$ the reconstruction schemes forestalled a deeper run and a deeper financial crisis.

Almost every bank that had suspended in the first half of 1893 had reconstructed and reopened by mid-August that year. However, the consequences of reconstruction were severe. Of the $£ 65$ million of deposits held in banks which ultimately reopened, $£ 9$ million was converted into preference shares or interminable deposits; $£ 42$ million had been repaid by 1901 , but the last repayment to depositors was made as late as 1918 (Royal Commission into Monetary and Banking Systems 1937). The 1890s depression was longer and more severe than that of 40 years later. In Victoria, the 'bank smash cancelled out the gold rushes and the land boom' (Shann 1930: 331).

The trauma of this banking crisis cast a long shadow. Meudell (1927) reflected decades later that 'France had her political terror in 1793 and Australia her financial terror in 1893'. The depression of the 1890s played a key role in developing the theory of the 'money power', a belief held by many in the labour movement that working people's savings were under the control of an alliance of government and British bankers. As they saw it, reconstruction had been a deliberate attempt by bankers to expropriate workers' earnings. 'As a means of robbery it is much simpler than burglary', declared the Sydney Worker in April 1893 (cited in Love 1984: 23).

The Great Depression of 1929-39 did not spark the sort of banking crisis in Australia that the country had experienced half a century earlier (Fisher and Kent 1999). One possible explanation for this is the highly conservative banking standards adopted by banks in the twentieth century. Banks adhered to a high reserves policy and shunned the sort of aggressive competition for 
deposits that characterised nineteenth-century banking. The reduction in the number of banks led to an 'oligopolistic' (Schedvin 1973: 598) banking structure. The conservative structure of the banking sector was also encouraged by depositors' flight to safety from trading banks to savings banks, the latter enjoying a guarantee derived from their government ownership.

One bank that failed during the Great Depression was the Primary Producers' Bank of Australia, a Queensland-incorporated bank with 42 branches in various states catering to farmers and graziers. When primary producers suffered rapid drops in the prices of their products, they were unable to repay their loans and others who had deposited funds began to withdraw. The bank suspended payments in 1931. Nevertheless, depositors received 19s $9 \mathrm{~d}$ in the $£ 1-$ in other words, almost 99 per cent of their original deposits (Royal Commission into Monetary and Banking Systems 1937).

Another bank that failed was the Government Savings Bank of New South Wales. The cause of this failure was more political than economic. With the election of the Lang government in New South Wales in October 1930, Lang's Nationalist opponents argued that the bank and its depositors would have to support Jack Lang's expansive public works program and commodity price guarantees. This led to a drain in deposits, which was exacerbated in early 1931 by the New South Wales Treasury's refusal to pay a large amount of interest on government stock. Further compounding the public's lack of confidence in the bank was a belief that it was subject to political interference. The Government Savings Bank closed in April 1931. The bank amalgamated with the Commonwealth Bank and reopened in December. These cases demonstrated to contemporaries that Commonwealth Bank support was discretionary. Throughout 1931, negotiations between the Government Savings Bank and the Commonwealth Bank were terse and protracted, and depositor confidence was not helped by public statements from the central bank that it was not bound to take over the NSW entity (Polden 1972).

Despite the relatively high degree of stability in Australia's financial sector, the banks were a target of much fractious debate and hostility during the Great Depression. The 1934 federal election centred on banking issues. Lyons was under pressure from the Country Party, which had been particularly affected by the contraction of credit, and for whom heterodox economic theories, most prominently Douglas Social Credit, had great appeal. Lyons agreed during the campaign to James Scullin's call for an inquiry into banking. It was not until August 1937 that the Royal Commission into Monetary and Banking Systems tabled its report in parliament. The Royal Commission was mostly concerned with the organisational structure of the Commonwealth Bank, the regulation 
of interest rates, credit and currency supply, and rejecting heterodox monetary theories. It also defended the existence of private banks, although a dissenting appendix written by Ben Chifley made the case for nationalisation.

Prudential regulation was not a focus of the Royal Commission, but it did nonetheless make a key recommendation which was to inform the Banking Act eight years later. Under the heading of 'Prevention of Bank Failures', the Royal Commission recommended that the Commonwealth Bank should be empowered to take over a bank that was unable to meet its obligations. The reasoning provided by the Royal Commission was that the inability of one bank to repay its depositors on demand would have system-wide significance. A failure in one bank could spill over into a failure in another bank. If a bank was unable to meet its obligations, the Commonwealth Bank would assume control of the bank in order conduct a thorough investigation of its finances. If the bank was essentially solvent, the Commonwealth Bank would act to shore up confidence. One action the Royal Commission suggested was possible to help confidence was publicly guaranteeing the deposits of the stricken bank. However, if the Commonwealth Bank determined that the bank was unsound, the central bank was to appoint officers to arrange for the bank to be wound up. In particular, 'as soon as it is in a position to do so, it should announce its estimate of the amount which the depositors may expect the receive' (Royal Commission into Monetary and Banking Systems 1937: 236). The clear suggestion from the Royal Commission was that the Commonwealth Bank would not offer a blanket guarantee of depositors' funds. The Commonwealth Bank was to advise banks if they were 'acting in such a manner as to endanger the whole system' and intervene if a bank was illiquid, but market discipline was to offer the ultimate depositor protection. Furthermore, the Royal Commission took pains to note that the interests of depositors were only of concern insofar as the failure of one bank could cause failures in the rest of the banking system; hence it ruled out any intervention in non-bank businesses.

In November 1938, the Treasurer, R. G. Casey, introduced the Commonwealth Bank Bill 1937-38 in the parliament. The Bill translated a large number of the recommendations of the Royal Commission into legislation, including the following provision for Commonwealth Bank takeovers of insolvent and illiquid banks:

If any bank informs the Commonwealth Bank of Australia that the first mentioned bank is unable to meet its obligations or if that bank suspends payment, the Commonwealth Bank of Australia may take all or if that bank suspends payment, the Commonwealth Bank of Australia may take all or any of the following actions, namely:

appoint an officer of the Commonwealth Bank of Australia to investigate the affairs of the first-mentioned bank; 
assume, for such time as the Board thinks necessary, the control of and carry on during that time the business of that bank; and

appoint a person to adminster the affairs of the bank or a liquidator to conduct its winding up. ${ }^{2}$

Casey's Cabinet memorandum for the Commonwealth Bank Bill stated that 'the fundamental basis of the recommendation is the fact that the failure of a bank to meet the demands of its creditors may seriously threaten the stability of the whole banking system'. The Commonwealth Bank would either offer 'some assistance such as a guarantee of deposits or a temporary loan', or, if the bank was insolvent, the Commonwealth Bank would appoint a receiver or liquidator (National Archives of Australia, A571, 1937/4600: 125). This was consistent with the Royal Commission's recommendations outlined above.

One contentious issue in the Lyons Cabinet, which became significant during the later debate under the Chifley government, was how much the Commonwealth Bank could compel banks to provide information about their financial wellbeing. The Cabinet rejected giving the Commonwealth Bank a power to require information from banks. It also rejected a similar recommendation of the Royal Commission which would have empowered the Treasurer to direct the Auditor-General to investigate the affairs of any bank. Casey considered that the recommendation 'presents substantial difficulties' and Cabinet ultimately rejected it (National Archives of Australia, A571, 1937/4600: 133-4).

In the event, the Commonwealth Bank Bill did not proceed beyond its secondreading speech. The death of Joseph Lyons and the advent of the Second World War meant that it was shelved, along with a Banking Bill that had not proceeded past the draft stage. Wartime Commonwealth control of banking and credit policy was first developed by voluntary agreement under the Menzies and Fadden governments. When John Curtin became prime minister in October 1941, his treasurer Ben Chifley announced that he would introduce banking control under National Security regulations, the first of which was gazetted in late November. While these regulations reflected some of the recommendations of the Royal Commission, these controls were directed towards specific wartime needs around inflation management and interest rate controls. Prudential regulation of banking was not a high priority.

2 Commonwealth Bank Bill 1937-38 (Cth) s.7AB (Austl.). 


\section{The preparation of the 1945 Banking Act}

The question of what the postwar political and regulatory environment would look like had been a live question even early in the war. There was a widespread belief that the end of the war would bring about depression, and banking regulation would be a key tool in restraining possible postwar inflation (Myers 1959; Stephens 1976). Shortly after gaining power, John Curtin told an interviewer that his government

... would be guided by the recommendations of the Royal Commission, which was never sought by the Australian Labor Party, but which no one except the Labor Party ever seems carefully to have read. We shall interpret Labor's currency and banking policy in the light of the recommendations of that Commission. We shall never upset those recommendations by prejudiced - although our predecessors ignored them by evasion. (Crisp 1960)

The looming end of the war offered a fixed deadline for regulatory change. Constitutionally, regulations under the National Security Act would expire at the end of hostilities. The Curtin government believed that if it failed to give the national security regulations a statutory foundation before the war was over it would be hard to do so in peacetime. In 1943, the government revisited the Lyons government's banking bills. However, these were soon discarded and work began on a fresh pair of bills (Schedvin 1992). In June 1944, the government began working with the Commonwealth Bank on detailed technical matters relating to banking (Butlin and Schedvin 1977).

While Curtin and Chifley had begun their government with a pledge to enact the strictures of the Royal Commission, the discussion over a statutory banking bill went further than that. Chifley told Cabinet that the government now saw the Royal Commission as 'somewhat out of date', given the controls had been enacted during the war (Crisp 1960). In September 1944 the press started reporting that the federal government would permanently exercise 'much closer and deliberate' control over banking than at any time in Australian history (The Age, 26 September 1944: 3). The government did not consult the private banks while developing the banking bill. In the early technical discussions between the government and the Commonwealth Bank, the former tended to accept the recommendations of the latter without much concern (Butlin and Schedvin 1977). This deference was not to last as the draft bill approached its finalisation.

The federal Cabinet considered the Banking Bill and the Commonwealth Bank Bill in a series of meetings between 10 and 17 January 1945, presided over by the acting prime minister Frank Forde while John Curtin was ill. The question of how the legislation should deal with a bank which was unable to meet its 
obligations was raised on the last day of those meetings. Cabinet records show the Curtin government had a substantially different policy intention from that of its predecessor. Rather than simply protecting depositors, the cabinet was informed that there would be a 'guarantee against loss which would be incorporated into the Banking Act'. This guarantee would apply 'to depositors as distinct from the Bank itself' (NAA: A2703, Vol. 1D).

Unfortunately, Cabinet minutes for the ensuing discussion do not identify the speakers, so we are unable to put names to statements. Nevertheless, the proposal sparked some debate among the Labor ministers. One objection raised at the meeting was that the guarantee would favour the private banks at the expense of the Commonwealth Bank, which the Labor Party was working to boost as a competitor to the private banking system: 'If the Government guaranteed the assets of depositors in private banks people would be encouraged to keep their accounts in the private banks ... the private banks would be buttressed up by the provision.' In response, advocates of the provision argued that the guarantee 'would become operative only in the case of doubt as to the private banks' stability' and that 'investment in the Commonwealth Bank should be encouraged by emphasising that the Commonwealth Bank was the only bank which had complete stability'. Another objection was raised that 'to be consistent' there ought to be a Commonwealth officer stationed in every private bank, providing a supervisory function. The bill's supporters responded by noting that the banks would be 'compelled to disclose completely their financial position, including the full market value of their assets' (NAA: A2703, Vol. 1D).

One participant stated during the meeting that it should be made clear that the claims of depositors will be protected'. The Cabinet finally approved that in the circumstances when the Commonwealth Bank assumed control of a private bank 'the depositors shall be guaranteed the security of their deposits' (NAA: A2703, Vol. 1D). However, the final legislation was not to be as unambiguous.

Records of the Attorney General's Department show how the Banking Act was redrafted to reflect changing views about the purpose of bank takeovers. The Royal Commission had offered its recommendations about Commonwealth Bank takeovers of illiquid and insolvent banks under the heading 'Prevention of Bank Failures'. In the draft act prepared in late 1944, the division was titled 'Provisions with respect to Banks unable to meet their obligations'. In late January 1945, this title was rewritten as 'Stability of Banks' (NAA A2863 1945/14 PART 2). Then in early February 1945 - that is, after the legislation had gone to cabinet - the title was rewritten again to become 'Protection of Depositors' (NAA A2863 1945/14 PART 4). Likewise, the marginal note beside section 13 was redrafted between January and February 1945 from a neutral 'Supply of information', to 'Commonwealth Bank to safeguard depositors', and 
then finally 'Commonwealth Bank to protect depositors' (NAA A2863 1945/14 PART 2; PART 4). These changes in terminology illustrate the shift in philosophy about the purpose of this provision and the banking legislation in general.

\section{Negotiating with the Commonwealth Bank}

It was only after the cabinet signed off on the government's policy that the issue of depositor protection was discussed with the Commonwealth Bank. Between 17 January and 30 January 1945 Frederick Wheeler, who had been the secretary to the government's Financial and Economic Policy Committee, informed the central bank that the government intended that the Commonwealth Bank should guarantee the deposits of a trading bank if and when it assumes control of the affairs of that bank' (RBA Archives, S-d-78). The proposal caused a flurry of activity within the Commonwealth Bank. The subsequent negotiation between the Commonwealth Bank and the Chifley government illustrates how the Commonwealth Bank saw the significance and effect of the deposit protection provisions, and how draft legislation was modified to take into account the central bank's concerns.

The major concern of the Commonwealth Bank was that taking over a distressed bank and guaranteeing depositors' funds could mean that any shortfall between assets and depositor promises would have to be covered by the Commonwealth Bank. It noted the government had not proposed to allocate any more capital to the Commonwealth Bank to protect against such an occurrence, and it was possible that wearing these losses could impede the operations of the central bank. In one memo (RBA Archives, S-d-78) the bank argued that:

In taking control of a bank it might have to assume responsibility for a much larger sum of deposits than the value of the assets it would acquire. In such circumstances the loss should be a national one and it would be reasonable for provision to be made for the Commonwealth Government to guarantee the bank against loss in the event of its assuming control of another bank.

The Commonwealth Bank emphasised the difference between the proposals of the Chifley government and the other major deposit-guarantee system internationally - that provided by the (United States') Federal Deposit Insurance Corporation (FDIC). In a note (undated but almost certainly produced on or around 1 February 1945) the Commonwealth Bank outlined what it saw as the key distinguishing features of the FDIC. The FDIC was a separate entity to the United States Treasury and the Federal Reserve system. It was an insurance system rather than a blanket guarantee. Banks were required to pay into the FDIC one-twelfth of 1 per cent per annum of their deposits in order to qualify for FDIC cover. The amount insured by the FDIC was limited to $\$ 5,000$ per 
deposit. Which banks were eligible for cover was at the discretion of the FDIC. Banks seeking insurance had to gain FDIC approval, and banks which the FDIC believed were unsound or had failed to comply with law or regulation could have their FDIC coverage terminated. The Commonwealth Bank's analysis emphasised the complex supervision arrangements that provided information about banking practices to the FDIC. Furthermore, the FDIC had its own bank examiners for supervisory purposes. As the Commonwealth Bank pointedly noted, the FDIC 'believes that whenever possible protection to depositors against loss through bank failure should be provided through preventive action rather than by paying off depositors after failure' (RBA Archives, S-d-78).

Looking at early drafts of the bill, the Commonwealth Bank observed that it was being expected to take control of a bank only very late in a process of failure, and only at the instigation of the private banks themselves. Only after a bank had informed the Commonwealth Bank that it 'considers that it is likely to become unable to meet its obligations or is about to suspend payment' or if the bank actually became unable to do so would the central bank be able to assume control. This would expose the Commonwealth Bank to liabilities over which it had no influence.

As a consequence, the Commonwealth Bank requested that the final legislation grant extra powers in addition to those in the draft bill: 'In the opinion of the officers of the Commonwealth Bank, it is desirable that the Commonwealth Bank should not be asked to assume responsibility for the repayment of deposits with other banks unless it is given suitable power to take preventive measures against bank failures' (RBA Archives, S-d-78). The first additional power was a discretionary power to assume control of a trading bank 'which the Commonwealth Bank considers may become unable to meet its obligations' (RBA Archives, S-d-78, emphasis added). Rather than being dumped with a failed bank - as the Casey legislation had provided - this way Commonwealth Bank would be able to take pre-emptive action and hopefully re-establish a bank's soundness before it became insolvent.

The second additional power the Commonwealth Bank requested was 'to maintain a continuous detailed inspection of the affairs of each bank' (RBA Archives, S-d-78). The draft bill seen by the Commonwealth Bank provided for periodic investigations of the books, accounts and transactions of each bank by the Auditor-General. This had been a recommendation of the Royal Commission and, as we have seen, one which the Lyons government rejected. However, as the government was now asking the Commonwealth Bank to blanket guarantee depositors' funds, Auditor-General supervision by itself was seen as inadequate to the prudential task. In the Commonwealth Bank's view, the Auditor-General's supervision would not have the 'technical skill and expertise of a trained banker' 
in determining whether a bank's investments 'have been, and are being, wisely made'. The Auditor-General's periodic audits should be supplemented by direct Commonwealth Bank investigatory powers (RBA Archives, S-d-78).

The third power that the Commonwealth Bank requested was to be enabled 'to give directions to banks about individual advances, investment, reserves $\&$ dividends' (RBA Archives, S-d-78). This would constitute far more expansive regulatory control over the banking sector than had been envisaged previously, and far exceeded the intent of the Royal Commission of the Lyons and Chifley government, which saw control of advances policy to be an instrument of monetary policy, rather than a prudential control. One Commonwealth Bank memo (RBA Archives, S-d-78) spells out the far-reaching implications of the deposit guarantee and the implied control over banking business:

[T] he suggested obligation upon the Bank to guarantee other bank deposits appears to cut across other provisions in the draft legislation.

For example, unless the Commonwealth Bank, in addition to the power to inspect, has power to assume control, it would have to have the power to inspect and to direct a bank regarding its investments. This would, in effect, take the management of another bank out of its own hands ... The power to direct would have to be applied in individual cases, whereas the whole intention of the advance policy provision is that broad lines of policy would be delineated ...

The implications of a direct guarantee of the nature proposed are such that it would be contended that this was just an indirect manner of achieving nationalisation.

The Commonwealth Bank proposed an alternative arrangement, modelled on the FDIC. In this alternative, the government would set up an insurance fund 'built up from premiums paid by the banks on their deposits'. The fund would have an inspector of banks, and depositor losses would be borne by the fund. This, in the Commonwealth Bank's view, would avoid 'objectionable' examinations of bank affairs, and eliminate the need for bank takeovers (RBA Archives, S-d-78).

The Curtin government rejected the alternative proposal of an FDIC-like insurance fund. The Labor Party had an antipathy towards contributory schemes that had been shown in the campaign against the Lyons government's proposed national insurance scheme (Coleman, Cornish and Haggar 2006; Watts 1987). It also declined to allot the Commonwealth Bank new funds. However, the proposal presented to the Labor caucus in late February 1945 and the bill presented to parliament in March granted many of the other powers the Commonwealth Bank had requested. The final bill allowed the Commonwealth Bank to require any bank to supply it with information relating to financial stability, and, if a bank failed to comply, appoint an officer to directly investigate 
the bank's affairs. Similarly, the proposal brought to caucus specifically noted that the Commonwealth Bank could assume control of a bank which was unable to meet its obligations 'according to its own statement or in the opinion of the Commonwealth Bank' (The Advertiser, 21 February 1945: 5). The final bill also provided for a range of penalties if the newly taken-over bank did not afford the Commonwealth Bank access to its financial information or submit its business to the Commonwealth Bank.

The Banking Bill was introduced into parliament on 9 March 1945, alongside the Commonwealth Bank Bill. Protection of depositors was covered under Division 2 of the bill. Section 11 read: 'It shall be the duty of the Commonwealth Bank to exercise its powers and functions under this Division for the protection of the depositors of the several banks' (Banking Bill 1945 (Cth) s.11 (Austl.)). The mechanism for resolving bank failures appeared in section 13, and stated that:

A bank which considers that it is likely to become unable to meet its obligations, or is about to suspend payment, shall forthwith inform the Commonwealth Bank.

Where a bank -

so informs the Commonwealth Bank;

becomes unable to meet its obligations or suspends payment; or

in the opinion of the Commonwealth Bank, is likely to become unable to meet its obligations or is about to suspend payment,

the Commonwealth Bank may -

appoint an officer of the Commonwealth Bank to investigate the affairs of the bank concerned; and

assume control of and carry on the business of that bank ...

Where the Commonwealth Bank has, in pursuance of subsection (2.) of this section, assumed control of the business of the bank, the Commonwealth Bank shall, subject to the next succeeding subsection, remain in control of and continue to carry on, the business of that bank until such time as -

the deposits with the bank have been repaid of the Commonwealth Bank is satisfied that suitable provision has been made for their repayment; and

in the opinion of the Commonwealth Bank it is no longer necessary for the Commonwealth Bank to remain in control of the business of the bank. (Banking Bill 1945 (Cth) s. 13 (Austl.)). 
Yet the legislation as written leaves us with a puzzle. There is nothing in the provisions introduced to parliament that explicitly states that deposits were to be guaranteed. Indeed, these provisions are perfectly internally consistent with the absence of a deposit guarantee. First, much was left to the Commonwealth Bank's discretion. The Commonwealth Bank 'may' assume control of an insolvent or illiquid bank, not 'must'. It is unclear what 'suitable provision' would constitute. Second, Section 15 of the Banking Act provided for depositor preference, which would seem to contradict any guarantee of deposits: 'In the event of a bank becoming unable to meet its obligations or suspending payment, the assets of the bank shall be available to meet that bank's deposit liabilities in Australia in priority to all other liabilities of the bank.'

In such circumstances as a bank's assets exceeded liabilities, this suggests some creditors, including depositors, might lose money.

Yet such a plain-English reading does not reflect the final agreement of the Curtin government cabinet, nor tally with the stated intention of the Curtin government in its discussion with the Commonwealth Bank a month earlier. While the government had not offered an FDIC-like contributory arrangement, it had nonetheless provided the greater supervisory powers which the central bank had argued were necessary in the context of a full deposit guarantee. Furthermore, as the next section will discuss, Labor parliamentarians believed that Division 2 offered depositors a full guarantee of their funds.

\section{The parliamentary debate}

How did parliament understand the bank deposit guarantee? Unfortunately, the implications of this provision were not presented to parliament as clearly as we might like. In his Second Reading speech on the Banking Bill, Chifley stated that the legislation had been written with the Royal Commission in mind but also took 'additional measures' to meet postwar conditions and learn from the wartime experience of banking control by regulation. One of the objects of the Bill was 'to safeguard depositors of the banks from loss'. Chifley did not use the word 'guarantee' to describe the protection of depositors. He focused mostly on the circumstances under which the Commonwealth Bank had a responsibility to assume control of a distressed bank. However, he did object to the 'considerable propaganda' which had been distributed in the preceding months suggesting that the interests of depositors 'would suffer under the proposed legislation'. In Chifley's view, the government's legislation had been deliberately framed to 'protect the depositors of the banks' (CPD, House of Representatives, 9 March 1945: 554). 
Neither was depositor protection a focus of the subsequent parliamentary debate. Arthur Fadden recognised that the bill provided for protecting depositors against bank failures, but said Chifley 'must have had his tongue in his cheek when he thought out that part of his speech' as there had been no bank failures in Australia since 1893, a success which he attributed to amendments to the Commonwealth Bank Bill in 1924. Robert Menzies focused much of his objections on the special accounts procedure, which extended the wartime arrangement whereby banks were required to lodge surplus funds with the Commonwealth Bank in order to effect profit control and manage inflation (CPD House of Representatives, 22 March 1945: 792). Menzies pointed out that the voluntary arrangement that had been negotiated by the Fadden government in 1941 for the special accounts procedure had explicitly identified that the special accounts would be used for depositor protection, but no such purpose was mentioned in the Banking Bill (CPD House of Representatives, 21 March 1945: 750). His concern was that depositors might be told, when withdrawing their funds, that their money had been frozen in the Commonwealth Bank.

Overall, the line of attack presented by opposition parties was that depositors' funds would be at risk from the bill, rather than protected by it. The question of Commonwealth Bank governance - the Commonwealth Bank Bill replaced the central bank's board with a single governor - had become a debate over political control of the Commonwealth Bank, and Labor's opponents argued that political control threatened the safety of depositors. However, Menzies recognised the existence of and 'had no intrinsic objection' to the depositor protection mechanism of Commonwealth Bank takeover (CPD House of Representatives, 21 June 1945: 3461). In this charged political debate, it is not obvious how the opposition parties saw the scope of the depositor protection provisions that is, whether they understood it as a reflection of the Royal Commission's recommendations or, as the Chifley government intended, a new unconditional guarantee on all deposits regardless of the solvency of individual banks.

However, one parliamentary debate is both indicative of the opposition's confusion and suggestive of attitudes towards the proposed scope of depositor protection. On 27 June 1945, the Country Party moved an amendment to replace the words 'for the protection of the depositors of the several banks' in section 11 with 'to ensure that each of the several banks shall meet its liabilities to its depositors, and safeguard the interest of borrowers' (CPD House of Representatives, 27 June 1945: 3673). The amendment was intended to underscore the opposition's argument that the advances policies dictated by the Commonwealth Bank and the special accounts procedure might prevent private banks from meeting their liabilities. Earle Page told parliament that, as the Commonwealth Bank would have power to 'maintain rigid operations of the private banks', it 'should ensure that depositors shall suffer no loss' (CPD House 
of Representatives, 27 June 1945: 3679). The Labor members dismissed these arguments. Lazzarini, the Minister for Home Security and Minister for Works, responded that the government's legal advisers had satisfied the government that the provision as written provided 'complete protection' for 'all persons who have any monetary interest in the private trading banks' (CPD House of Representatives, 27 June 1945: 3674). The Country Party amendment was voted down.

Indeed, in the process of defending against claims that the banking legislation placed depositor funds at risk, Labor parliamentarians offered a clearer outline of the purpose behind those provisions than Ben Chifley had when introducing the bill. For instance, Allan Fraser, the member for Eden Monaro, responded to the 'deliberate attempt [to] scare the depositors in private trading banks' by saying that 'for the first time in the history of this country' banking legislation would 'provide a real and an effective guarantee of the safety of bank deposits' (CPD House of Representatives, 5 June 1945: 2521). The Labor member for Perth, Tom Burke, said the bill's regulations would 'ensure that the public shall be protected against ... losses of money' (CPD House of Representatives, 21 June 1945: 3468). The Tasmanian Senator Charles Lamp described the provisions as 'the most important in the bill' (CPD Senate, 20 July 1945: 4338). Charles Morgan, the Labor member for Reid, told parliament that the legislation would have allowed the banks that failed during the Great Depression 'to fall back upon the Commonwealth Bank in order to protect their depositors and borrowers' (CPD House of Representatives, 27 June 1945: 3674).

The Banking Bill passed the parliament in November 1945. In the 1947 debate over bank nationalisation, the shape of the deposit guarantee was used to reassure parliament and voters about the security of their funds. Chifley told parliament that:

The truth is that the banking legislation of 1945 created a precedent in the financial history of the British Empire. It gave to the people of Australia a guarantee that all depositors would receive their money on demand, even if those deposits were held in a private bank which had gone into liquidation. In effect, the Labor Government was the first government of any country which gave to depositors a guarantee that their interests would be protected ... the Government has endeavoured to give to those people who have deposited money in private banking institutions what is in effect a guarantee that they will not lose their money. (CPD House of Representatives, 18 November 1947: 2188)

Likewise, John Dedman, who had been the Labor minister for postwar reconstruction at the time of the Banking Act's introduction, told an audience in the wake of the defeat of nationalisation that 'very few people in Australia 
today were aware that all depositors' accounts in private trading banks were guaranteed by the Commonwealth government, under the 1945 Banking Act' (Port Lincoln Times, 17 November 1949: 2).

\section{The deposit guarantee disappears}

The Chifley government saw its banking legislation as one of the major pegs on which its social and economic policy were hung. Presenting the White Paper on Full Employment to parliament, Dedman said that it was 'closely linked' to the banking reforms, as 'the basic purpose of the banking legislation is to ensure that no out-worn financial prejudices or the resistance of vested interests will ever again be a bar to the achievement of full employment' (CPD House of Representatives, 30 May 1945: 2238). As late as 1973, Gough Whitlam was referring to the deposit guarantee as the fundamental bargain of Australian financial regulation: 'No bank registered under Australian Parliament legislation can go bankrupt. In return for that guarantee against loss, banks pursue a lending policy which the government of the day approves' (CPD House of Representatives 23 May 1973: 2480).

The mechanism through which the Curtin-Chifley government believed deposits were guaranteed has never been tested. However, in 1979 the RBA did consider a takeover of the Bank of Adelaide under the Banking Act provisions. Discussions within the RBA about the viability of this process give us an image of how the central bank saw its obligations to depositors before the changes to financial regulation in the 1980s.

In early 1979, the Bank of Adelaide faced imminent failure. The crisis was caused by the fact that its wholly owned subsidiary, the Financial Corporation of Australia (FCA), was virtually insolvent (Merrett 1985). The Bank of Adelaide's capital was not sufficient to cover FCA's losses, and the bank started looking for external support, first with the federal government, and second with the RBA. In a meeting on 5 May 1979, the RBA offered the Bank of Adelaide an ultimatum: it was to find a larger Australian trading bank to merge with under any terms. Unless arrangements for a merger were made, the RBA would use its powers under section 13 of the Banking Act to take over operation of the bank (RBA Archives, D08-53041). This would occur, RBA governor Harry Knight allegedly told the Bank of Adelaide, 'whether it is lawful or not' (Sydney Morning Herald, 7 November 1979: 25). A potential merger between the Bank of Adelaide and the ANZ Banking Group was announced on 22 May 1979. The ANZ merger was accepted by Bank of Adelaide shareholders in October 1979, albeit under a cloud of ill-will towards the RBA (de Meyrick 2003: 317). 
The Bank of Adelaide rescue operation exposed for the RBA many of the weaknesses of the Banking Act's provisions. One contested question was whether the Commonwealth Auditor-General would be able to grant the takeover authority to the RBA given that it was the FCA rather than the Bank of Adelaide which was directly in trouble. Furthermore, unless it was informed by the Bank of Adelaide that the bank was unable to meet its obligations, the RBA would have to act on a report by the Auditor-General, and action might be tied up in court (RBA Archives, D15-268223). Thus the RBA concluded that such action 'depends to a considerable extent on the good sense' of Bank of Adelaide management (RBA Archives, D15-217021).

More pressingly, there was considerable uncertainty within the RBA as to its obligations in the case of a bank takeover. A memorandum prepared by the RBA's Banking and Finance Department in April 1979 stood by the established principle that 'insolvent companies should be allowed to die'. However, it also saw a tension between this principle and the fact that 'the community has taken special measures to afford investors in certain institutions some protection in the event of default. This attitude is inherent in the protection of depositors as implied in the Banking Act' (RBA Archives, D15-184639, emphasis added). Furthermore, RBA officials were assuring worried Bank of Adelaide depositors that the Banking Act's provisions ensured 'they can't lose money' (RBA Archives, D15-268229).

The introduction of foreign banks into Australia in the early 1980s and the dismantling of much of the financial regulatory apparatus that was brought in by the Banking Act was accompanied with a codification and formalisation of prudential standards. This necessitated a clarification of the status of depositor protection. The 1981 Campbell Committee had viewed deposit insurance as an unnecessary substitute for the existing depositor protections of the Banking Act (Committee of Inquiry into the Australian Financial System 1981). The Hawke government's Martin Review Group rejected a government deposit guarantee (Australian Financial System Review Group 1984). Thus, in 1985, the governor of the Reserve Bank stated that 'the Reserve Bank is the guardian, not the guarantor, of depositors' interests' (Johnston 1985). The 1997 Wallis Inquiry, observing the decline in government ownership and therefore the subsequent decline in explicit guarantees, stated blankly that 'the government should not provide an absolute guarantee in any area of the financial system' (Financial System Inquiry 1997: 192). The 2004 Davis Study of Financial System Guarantees, which followed the recommendations of the HIH Royal Commission, described the existing regulatory framework as follows: 
When dealing with the insolvency of a financial institution, the prudential framework tries to ensure that there is sufficient leeway to identify and manage the exit of a troubled institution before significant losses to certain stakeholders accrue. However, this is not always possible and the customers and other creditors of a financial institution may not always be repaid in full. (Davis 2004)

Yet to a significant degree the provisions governing banks which are unable to meet their obligations to depositors remained the same between 1945 and 2008, the year that the Rudd government introduced the Financial Claims Scheme as an explicit deposit guarantee. The Banking Act 1945 was superseded by the Banking Act 1959, which transferred the provisions with negligible change. Those provisions remained intact up to the establishment of the Australian Prudential Regulatory Authority (APRA) in 1998. Amendments to the Banking Act in 1998 made specific provision for insolvent authorised deposit-taking institutions (ADIs) to be wound up under corporations law, and granted the depositor priority that banks had been subject to since 1945. Yet the Banking Act maintained the process formulated by the original 1945 Act by which banks - now all ADIs - are taken over, but now by APRA rather than the Reserve Bank. Even after the introduction of the Rudd government's Financial Claims Scheme in 2008, the Banking Act 1959 provides that APRA terminate its control of an ADI either when 'deposit liabilities have been repaid or APRA is satisfied that suitable provision has been made for their repayment'.

This history calls out for explanation. The clear legislative intent of the Curtin-Chifley government was that the Commonwealth Bank would guarantee depositors' funds in the case of a bank failure. This is what Ben Chifley told the cabinet, Labor members told the parliament, the government told the Commonwealth Bank, and Labor supporters told the public in later years. However, the text of the Banking Act did not explicitly reflect this guarantee. Indeed, as written the relevant provisions of the Banking Act differed in only minor ways from parallel provisions in the Lyons government's proposed banking legislation, which was deliberately not intended as a blanket guarantee of depositors. The deposit guarantee in 1945 was explicit but not explicit in statute.

There are a few possible implications of this. It is possible that over time the RBA deliberately interpreted the Banking Act against the original intent of parliament. Denying that an explicit guarantee existed relieved the RBA of financial liability for depositors of failed banks. Alternatively, the provision's disuse - there were three decades between the parliamentary debate and the consideration of taking over the Bank of Adelaide - meant that institutional memory of the 1945 discussions was lost. An ahistorical reading of the Banking Act would make Division 2 look unproblematic. Certainly the challenge of simply taking control of the Bank of Adelaide was formidable enough without 
considering how to respond to depositors' demands once control was achieved. And the Banking Act has been picked over by inquiry after inquiry since the Campbell committee, none of which has considered that Division 2 implies anything other than what it says. Explanations for why the Curtin-Chifley government failed to give surer statutory footing to their intent are going to be even more speculative.

The Financial Stability Forum (2001) emphasises that an effective deposit insurance system is one in which the scope and limitations of the guarantee are well-known and understood by the public (see also Garcia 1999). Yet how well the public understands deposit guarantees has attracted surprisingly little study (Bartiloro 2011; Bowyer, Thompson and Srinivasan 1986; Inakura and Shimizutani 2010; Reserve Bank of Australia 2006; Sträter, Cornelißen and Pfingsten 2008). However the legislation was to be interpreted by policymakers in later decades, the Curtin-Chifley government fuelled a public perception that the Commonwealth Bank would bail out depositors in a failed bank. In subsequent decades, the RBA rowed back this perception by stating that no such guarantee existed, and that depositors needed to exercise discipline through the market and monitor their bank's performance. Their attempts to manage these perceptions would have been negatively affected by the Victorian government's guarantee of depositors of the State Bank Victoria in 1990 and the Commonwealth support for the insurance firm HIH in 2001. When the Rudd government guaranteed all ADI depositors in 2008, this can be seen as a reversion to the policy of its Labor predecessors six decades earlier.

\section{References}

Australian Financial System Review Group 1984, Australian financial system: Report of the Review Group, Australian Government Publishing Service, Canberra.

Bartiloro, L. 2011, 'Is your money safe? What Italians know about deposit insurance', Bank of Italy Occasional Paper, no. 104.

Bowyer, L.E, Thompson, A.F. and Srinivasan, V. 1986, 'The Ohio banking crisis: A lesson in consumer finance', The Journal of Consumer Affairs: 290-9.

Butlin, S.J. 1953, Foundations of the Australian monetary system 1788-1851, Melbourne University Press, Melbourne.

_ 1961, Australia and New Zealand Bank: the Bank of Australasia and the Union Bank of Australia Limited, 1828-1951, Longmans, London. 
Butlin, S.J. and Schedvin, C.B. 1977, War economy, 1942-1945, Australian War Memorial, Canberra.

Coghlan, T.A. 1918, Labour and industry in Australia from the first settlement in 1788 to the establishment of the Commonwealth in 1901, 4 vols, Oxford University Press, London, New York.

Coleman, W.O., Cornish, S. and Hagger, A.J. 2006, Giblin's Platoon: The trials and triumph of the economist in Australian public life, ANU E Press, Canberra.

Committee of Inquiry into the Australian Financial System 1981, Final report, AGPS, Canberra.

Crisp, L.F. 1960, Ben Chifley: A biography, Longmans, London.

Davis, K. 2004, Study of Financial System Guarantees, Commonwealth of Australia, Canberra.

de Meyrick, R. 2003, Rymill: His Life and Times, Aldgate Publishers, Benalla, Victoria.

Dowd, K. 1992, 'Free banking in Australia', in K. Dowd (ed.), The Experience of Free Banking, Routledge, London; New York: xi.

Edwards, V. and Valentine, T.J. 1998, 'From Napier to Wallis: Six Decades of Financial Inquiries', The Economic Record 74(226).

Financial Stability Forum 2001, Guidance for Developing Effective Deposit Insurance Systems, Financial Stability Forum, Basel, Switzerland.

Financial System Inquiry 1997, Final report, Australian Government Publishing Service, Canberra.

Fisher, C. and Kent, C. 1999, Two Depressions, One Banking Collapse, Reserve Bank of Australia, Sydney.

Garcia, G.G. 1999, Deposit Insurance-A Survey of Actual and Best Practices, International Monetary Fund.

Giblin, L.F. 1951, The growth of a central bank; the development of the Commonwealth Bank of Australia, 1924-1945, Melbourne University Press, Melbourne.

Goldsworthy, B., Lewis, D. and Shuetrim, G. 2000, APRA and the Financial System Inquiry, Australian Prudential Regulatory Authority.

Gray, R.P. 2004, 'Australia's Implicit Deposit Insurance: Should it be Reconsidered?', Australian Accounting Review 14(1): 41-52. 
Hickson, C.R. and Turner, J.D. 2004, 'Free banking and the stability of early joint-stock banking', Cambridge Journal of Economics 28(6): 903-19.

Hogan, W.P. and Sharpe, I.G. 1990, 'Prudential Supervision of Australian Banks', The Economic Record 66(2): 127-45.

Inakura, N. and Shimizutani, S. 2010, 'Deposit insurance and depositor discipline: Direct evidence on bank switching behaviour in Japan', Applied Economics 42(26): 3401-15.

Johnston, R. 1985, 'Prudential Supervision of Banks', Bulletin/Reserve Bank of Australia, March.

Love, P. 1984, Labour and the money power: Australian Labour Populism 18901950, Melbourne University Press, Melbourne.

Merrett, D.T. 1985, ANZ Bank: a history of Australia and New Zealand Banking Group Limited and its constituents, Allen \& Unwin, Sydney.

— 1993, 'Preventing Bank Failure: Could the Commercial Bank of Australia have been saved by its peers in 1893?', Victorian Historical Journal 64(2): 122-41.

_2013, 'The Australian Bank Crashes of the 1890s Revisited', Business History Review 87(3): 407-29.

Meudell, G.D. 1927, The Romance of Australian Banking, Acme Press, Melbourne.

Mitchell, A. 2006, 'Why deposit insurance is the way to go', The Australian Financial Review, 3 April.

Myers, M.G. 1959, 'The Attempted Nationalization of Banks in Australia, 1947', The Economic Record 35(71).

Polden, K. 1972, 'The Collapse of the Government Savings Bank of New South Wales, 1931', Australian Economic History Review 12(1).

Pope, D. 1987, Bankers and banking business, 1860-1914, The Australian National University, Canberra.

Quiggin, J. 2002, 'Savings need a safety net', Australian Financial Review, 29 August.

Reserve Bank of Australia 2006, Financial Stability Review, Reserve Bank of Australia, Sydney.

Royal Commission into Monetary and Banking Systems 1937, Report, Commonwealth Government Printer, Canberra. 
Schedvin, C.B. 1973, 'A Century of Money in Australia', Economic Record 49(4): 588-605.

— 1992, In reserve: central banking in Australia, 1945-75, Allen \& Unwin, Sydney.

Schuler, K. 1992, 'The world history of free banking: An overview', in K. Dowd (ed.), The Experience of free banking, Routledge, London; New York: xi.

Shann, E.O.G. 1930, An economic history of Australia, Cambridge University Press, Cambridge, UK.

Stephens, D. 1976, 'The Effect of the Great Depression on the Federal Labor Governments, 1941-49', Australian Journal of Politics \& History 22(2).

Sträter, N, Cornelißen, M. and Pfingsten, A. 2008, 'Deposit Insurance: An Empirical Study of Private Investors' Knowledge and Perception', www.fbv.kit.edu/symposium/11th/Paper/30Posters/Straeter.pdf.

Sykes, T. 1988, Two centuries of panic: a history of corporate collapses in Australia, Allen \& Unwin, Sydney.

Thomson, D. and Abbott, M. 2000, 'Australian Financial Prudential Supervision: An Historical View', Australian Journal of Public Administration 59(2): 75-88.

Turner, H.G. 1904, A history of the Colony of Victoria from its discovery to its absorption into the Commonwealth of Australia, 2 vols., Longmans, Green and Co., London.

Watts, R. 1987, The foundations of the national welfare state, Allen \& Unwin, Sydney.

Waugh, J. 1992, 'Company law and the crash of the 1890s in Victoria', University of New South Wales Law Journal 15(2): 356-88. 
This text is taken from Agenda, Volume 22 - Number 1, 2015, edited by William Coleman, published 2015 by ANU Press, The Australian National University, Canberra, Australia. 